УДК. 582.29(571.54)

DOI: $10.18101 / 2542-0623-2020-3 / 4-60-76$

\title{
БИОМАССА ЛИШАЙНИКА ХANTHOPARMELIA CAMTSCHADALIS В СТЕПНЫХ СООБЩЕСТВАХ БУРЯТИИ
}

\section{Т. М. Харпухаева}

\author{
(c) Харпухаева Татьяна Михайловна \\ кандидат биологических наук, \\ Институт общей и экспериментальной биологии СО РАН \\ Россия, 670047, г. Улан-Удэ, ул. Сахьяновой, 6 \\ takhar@mail.ru
}

\begin{abstract}
Аннотация. Целью настоящей работы является изучение продуктивности и проективного покрытия Xanthoparmelia camtschadalis (Ach.) Hale в аридных экосистемах Республики Бурятия. Ранее продуктивность лишайников в открытых травяных экосистемах России не изучалась, что особенно актуально для изучения функциональной роли лишайников в фитоценозах аридных зон. Xanthoparmelia camtschadalis - ксеромезофитный лишайник семейства Parmeliaceae, широко распространенный в северной Евразии. Вид обитает в степях и полупустынях от Восточной Европы до территорий Монголии и Китая, доходя до запада Северной Америки. Исходным материалом послужили данные, полученные в ходе изучения запаса надземной биомассы лишайников в полевые сезоны 2010-2016 гг. на двух трансектах: первый был заложен через Баргузинскую котловину от Баргузинского до Икатского хребта; второй — в Тапхарской котловине (Селенгинское среднегорье). Значения биомассы от 0,5 до 435,2 кг/га, в среднем 96,44 кг/га. Проективное покрытие лишайников (участки с доминированием $X$. camtschadalis) колеблется от 1 до $30 \%$, в среднем $8 \%$. Выявлена слабая положительная корреляция между биомассой и проективным покрытием X. camtschadalis. Между проективным покрытием сосудистых растений и биомассой лишайника связь отсутствует. Отмечено положительное влияние слабого либо умеренного выпаса. Таким образом, проективное покрытие и биомасса $X$. camtschadalis является индикатором состояния травянистых экосистем.
\end{abstract}

Ключевые слова: Xanthoparmelia camtschadalis (Ach.) Hale; продуктивность; степи; биомасса; лишайник; проективное покрытие.

\section{Для цитирования}

Харпухаева T. М. Биомасса лишайника Xanthoparmelia Camtschadalis в степных сообществах Бурятии // Природа Внутренней Азии. Nature of Inner Asia. 2020. № 3/4(16). C. 60-76. DOI: 10.18101/2542-0623-2020-3/4-60-76

\section{Введение}

В статье приводятся данные по биомассе и проективному покрытию вида Xanthoparmelia camtschadalis (Ach.) Hale (далеe Xca), одного из эдификаторов напочвенного покрова в степных котловинах Республики Бурятия. Хca листоватый лишайник, неприкрепленный таллом, хотя имеет рудиментарные 
ризины, поверхность гладкая, блестящая, от желтовато- до серовато-желтоватозеленоватого цвета, лопасти раздельные, ветвистые, часто скручиваются в трубочку. Вид широко распространен на территории республики, доходя до верхнего течения р. Баргузин на севере и границы с Монголией на юге. Вид предпочитает мелкодерновинно-злаковые, чиевые, осочковые, щебнистые степи.

Изучение продуктивности лишайников аридных регионов в России не проводилось. В Советском Союзе видовой и ценотический состав исследовали 3. Джураева и С. В. Лысенко в пустынях Средней Азии [Лысенко, 1969; Джураева, 1979]. Биомасса лишайников упоминается в работах 3. Джураевой [Джураева, 1993; Джураева, Абдурахимова, 1986]. В России главным образом проводился учет продуктивности ягеля как кормового ресурса северного оленя, в частности, прирост видов рода Cladonia [Андреев, 1954; Щелкунова, 1979; Рыкова, 1980; Магомедова и др., 1986; Морозова, Эктова, 2007]. Есть отрывочные сведения по биомассе видов рода Xanthoparmelia при исследованиях продуктивности травяных экосистем, например, в исследованиях М. Н. Караваева [1976], Ч. Н. Самбыла [2007, 2014], М. Г. Меркушевой [Меркушева, Лаврентьева, 2018] или разовое измерение биомассы как ресурсного вида в Астраханской области [Закутнова, 2013]. В то время как биомассе сосудистых растений посвящено большое количество исследований в виду их кормовой ценности. Это касается и Республики Бурятия: большое количество исследователей занималось изучением продуктивности степных и луговых фитоценозов [Рещиков, 1961; Осипов, Осипова, 1972; Рудьман, 1972; Зарубин, Фролова, 1972; Меркушева и др., 2006; Бойков и др., 2009; Рупышев и др., 2013; и др.]. В соседней Монголии биомасса лишайников изучалась более интенсивно [Бязров, 1976, 1986, 1988, 2015; Hauck et al., 2007]. В Республике Бурятия изучение биомассы лишайников было начато недавно [Харпухаева, 2010, 2013; Гунин и др., 2018]. Поэтому изучение продуктивности лишайников представляется актуальным в связи с полным отсутствием данных об участии лишайников в сложении аридных фитоценозов.

\section{Материалы и методы}

Исходным материалом послужили данные, полученные в ходе изучения запаса надземной биомассы и проективного покрытия лишайников в полевые сезоны 2010-2016 гг. Изначально предполагалось, что продукция и проективное покрытие лишайникового яруса тем меньше, чем больше пастбищная дигрессия в степных экосистемах. Материалы были собраны в Баргузинской котловине (Баргузинский и Курумканский районы РБ) и на Селенгинском среднегорье (Тапхарская котловина, Иволгинский район РБ) (рис. 1).

Для изучения биомассы лишайника закладывались пробные площади $\left(100 \mathrm{~m}^{2}\right)$, на которых делалось геоботаническое описание, учитывалось проективное покрытие сосудистых растений и лишайников. При описании отмечали расположение площадки в микро(нано)рельефе, общее проективное покрытие лишайников, полный видовой состав лишайников, проективное покрытие каждого вида в процентах [Понятовская, 1964; Родин и др., 1967]. Всего было сделано 14 пробных площадей в Баргузинской котловине и 6 - в Тапхарской. Для оценки состава и структуры видов все описания были проанализированы с помощью программы IBIS [Зверев, 2007]. Расчеты были произведены по шкалам пастбищной дигрессии, увлажнения и богатства-засоленности почв [Цаценкин и др., 1974]. 


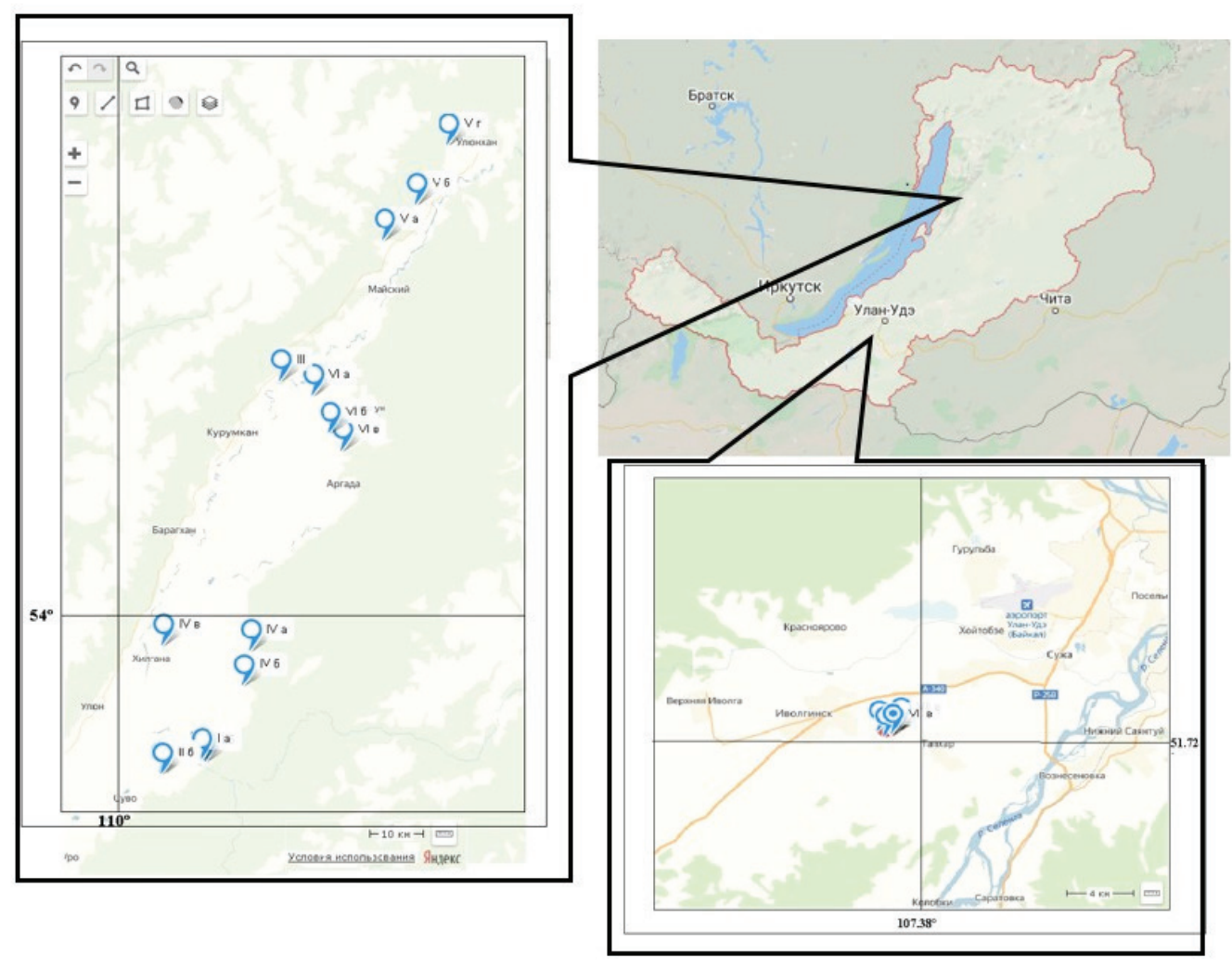

Рис. 1. Карта-схема исследуемой территории.

На врезках: слева - Баргузинская котловина; справа внизу — Тапхарская котловина

На каждой пробной площади закладывалось пять учетных площадок - площадью 20х20 см, на которой собирались и учитывались талломы лишайника. Вес определялся в воздушно-сухом состоянии. В основной массе сборы были моновидовые, если сопутствовали другие виды лишайников, то они удалялись из проб и взвешивались отдельно, и в настоящей статье не задействованы. Поскольку перед нами не стояла задача оценить флористическую насыщенность, такая минимальная повторность обеспечивает достоверное количество данных.

Климат на исследуемых территориях засушливый, резкоконтинентальный. По данным исследователей [Болданов, Мухин, 2019], основанных на анализе климатических показателей по метеостанциям Республики Бурятия за период с 1970 по 2015 г. на территории исследования за последние 45 лет наблюдаются выраженные изменения климата. Из них максимальное изменение прослеживается в засушливом северо-восточном секторе (баргузинском), где значительное потепление сочетается с существенным снижением количества осадков, в то же время в центрально-прибайкальском лесостепном районе выраженное потепление сочетается с отсутствием тренда суммарных осадков.

Баргузинская котловина (длина около 200 км, ширина 35 км) - одна из крупнейших суходольных впадин Байкальской рифтовой зоны. Борта котловины поднятия Баргузинского и Икатского горных хребтов. Чтобы охарактеризовать 
сложный рельеф, был заложен профиль от склонов Икатского хребта (окрестности с. Ина) по дну долины (окрестности сел Суво, Элэсун) к предгорьям Баргузинского хр. (окрестности сел Алла, Кучигер). Таким образом, в Баргузинской котловине получился меридиональный транссект общей протяженностью 110 км. Пробные площади были представлены степными сообществами (окрестности сел Элэсун, Ина, Кучигер) и залежами (окрестности сел Могойто, Арзгун). Залежные сообщества были довольно однотипными, поэтому из 10 сделанных описаний, в статье использовано одно (VIб). Были исследованы следующие типы сообществ: тимьяново-бесстебельнолапчатковая, леймусовая, леймусово-осочковая, холоднополынно-чиевая, субвискозополынно-чиевая, хамеродесово-полынная степи и пр. Степные сообщества используются как круглогодичные пастбища и как зимние для отгонного скотоводства. Пастбищная нагрузка на всех изученных участках была примерно одинаковой, возрастая по мере приближения к населенным пунктам.

Тапхарская котловина - бессточная засоленная котловина между отрогами Ганзуринского хребта (Селенгинское среднегорье) и долинами рек Селенга и Иволга. Днище котловины имеет пологоволнистый рельеф в пределах высот 511-580 м и расположено среди низких останцовых гор с диапазоном абсолютных высот 710-854 м. В окрестностях с. Тапхар был заложен профиль через котловину в направлении с запада на восток: равнина, склон, днище котловины, склон, высокая равнина. Засушливый климат обусловил формирование сухостепного ландшафта со сплошным распространением каштановых мучнисто-карбонатных почв [Мангатаев и др., 2010]. Днище котловины находится под залежью. Целинные варианты сохранились на неудобьях — склонах и на вершинах останцов. В экологическом составе преобладают растения ксерофильной группы, на долю эуксерофитов приходится $82 \%$, а мезоксерофитов - $18 \%$. Эколого-ценотический комплекс преимущественно представлен горностепными видами [Балданов и др., 2012]. Сообщества используются для круглогодичного выпаса.

Тапхарская котловина является примером агроценозов, в настоящее время представленная залежами (последствия распашки в 2010-е гг.) на днище котловины и степными сообществами по склонам. Деградация растительных сообществ Тапхарской котловины в сочетании с круглогодичной пастбищной нагрузкой остается высокой. Баргузинская котловина в силу своего размера сочетает в себе малонарушенные, пастбищно-деградированые и залежные сообщества, где сукцессии спустя 20 лет после прекращения распашки представлены в основном двумя первыми стадиями: бурьянистой и корневищной [Гунин и др., 2018].

\section{Геоботанические описания}

Баргузинская котловина

I. Баргузинский район, подножие Икатского хр., окрестности с. Ина: I a (рис. 2.1) — ровное место на окраине с. Ина, выс. 520 м, 5304'28,5" с. ш., $110^{\circ} 14^{\prime} 28^{\prime \prime}$ в. д., 17 VI 2010, твердоватоосоково-тимьяново-бесстебельнолапчатковая степь (Carex duriuscula C. A. Meyer, Thymus baicalensis Serg., Potentilla acaulis L., P. bifurca L., Cleistogenes squarrosa (Trin.) Keng, Veronica incana L., и др.); I б (рис. 2.6) там же, склон горы юго-западной экспозиции, выс. 668 м, 53²4’17» с. ш., 110¹5'14" в. д., 21 VI 2010, бесстебельнолапчатково-пульсатиллово-холоднополынная степь 
(Artemisia frigida Willd., Pulsatilla turczaninovii Krylov et Serg., Potentilla acaulis L., P. bifurca L., Carex duriuscula C.A. Meyer, Cleistogenes squarrosa (Trin.) Keng, Veronica incana L., Thymus baicalensis Serg.).

II. Баргузинский район, долина р. Баргузин, г. Кардига, окрестности с. Суво: II а — долина, выровненная макушка увала, выс. 568 м., 5343'3" с. ш., 1106'55" в. д., 22 VI 2010, субвискозополынно-чиевая степь (Artemisia obtusiloba subsp. subviscosa (Turcz. ex Bess.) Krasnob., A. scoparia Waldst. et Kit., Achnatherum splendens (Trin.) Nevski, Potentilla acaulis L., Carex duriuscula C.A. Meyer, Veronica incana L., Thymus baicalensis Serg.); II б (рис. 2.5) - склон горы, выс. 668 м, 5342'58" с. ш., 1107'13» в. д., 22 VI 2010, хамеродесово-полынная степь (Artemisia scoparia Waldst. et Kit., A. laciniata Willd., Chamaerhodos erecta (L.) Bunge, Potentilla acaulis L., Carex duriuscula C. A. Meyer, Veronica incana L., Thymus baicalensis Serg.).

III. Курумканский район, долина р. Баргузин, окрестности с. Могойто, выс. 527 м, 54²4'26,6" с. ш., 110²7'39,7" в. д., 25 VI 2016, твердоватоосоковая степь (рис. 2.2) (Carex duriuscula C. A. Meyer, Potentilla acaulis L., Pulsatilla turczaninovii Krylov et Serg., Oxytropis glandulosa Turcz., Aster alpinus L., Artemisia scoparia Waldst. et Kit., Veronica incana L.).

IV. Курумканский район, долина р. Баргузин, окрестности с. Элэсун: IV a (рис. 2.3) - 587 м, 535' $46.4^{\prime \prime}$ с. ш., $110^{\circ} 23^{\prime} 34.7^{\prime \prime}$ в. д., 26 IX 2015, ковыльная степь (Stipa krylovii Roshev., Potentilla acaulis L., Carex duriuscula C.A. Meyer, Pulsatilla turczaninovii Krylov et Serg., Veronica incana L.); IV б - склон западной экспозиции Икатского хр., выс. 590 м, 5352'47.1” с. ш., 110²2’14.5” в. д., 26 IX 2015, степь злаково-разнотравная (Cleistogenes squarrosa (Trin.) Keng, Bromopsis korotkiji (Drobov) Holub, Agropyron cristatum (L.) Beauv., Leymus chinensis (Trin.) Tzvelev, Achnatherum splendens (Trin.) Nevski, Aster alpinus L., Heteropappus biennis (Ledeb.) Tamamsch. ex Grub., Veronica incana L., Thymus baicalensis Serg., Carex duriuscula C. A. Meyer, Artemisia scoparia Waldst. et Kit., Potentilla acaulis L., P. bifurca L.);

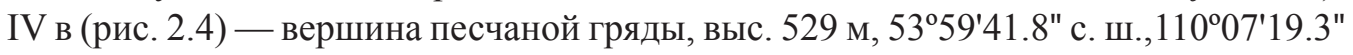
в. д., 26 IX 2015, твердоватоосоковая степь (Carex duriuscula C. A. Meyer, Artemisia scoparia Waldst. et Kit., Achnatherum splendens (Trin.) Nevski).

V. Курумканский район, долина р. Баргузин, окрестности с. Алла, степь у подножия Баргузинского хребта: V a - выровненное дно котловины, выс.

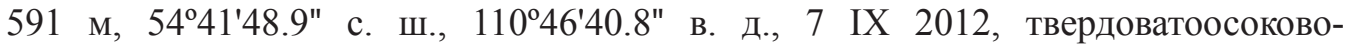
лапчатковобесстебельная степь (Carex duriuscula C.A. Meyer, Potentilla acaulis L., Thymus baicalensis Serg., Veronica incana L., Pulsatilla turchaninovii Krylov et Serg., Aster alpinus L.); V б — там же, выс. 590 м, 5441'50.4" с. ш., 11046'43.2" в. д., 7 IX 2012, твердоватоосоково-лапчатковобесстебельная степь (Carex duriuscula C. A. Meyer, Potentilla acaulis L., Pulsatilla turczaninovii Krylov et Serg., Aster alpinus L., Veronica incana L.); V в - склон юго-юго-западной экспозиции Баргузин-

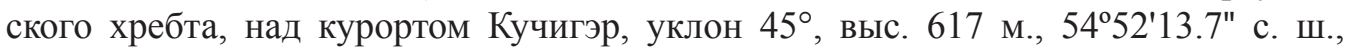
11058'39.2" в. Д., 7 IX 2012, холоднополынно-тимьяново-лапчатковобесстебельная степь (Artemisia frigida Willd., Thymus baicalensis Serg., Potentilla acaulis L., Carex duriuscula C. A. Meyer, Pulsatilla turczaninovii Krylov et Serg., Aster alpinus L., Veronica incana L.). 
T. M. Харпухаева.

Биомасса лишайника Xanthoparmelia Camtschadalis в степных сообществах Бурятии
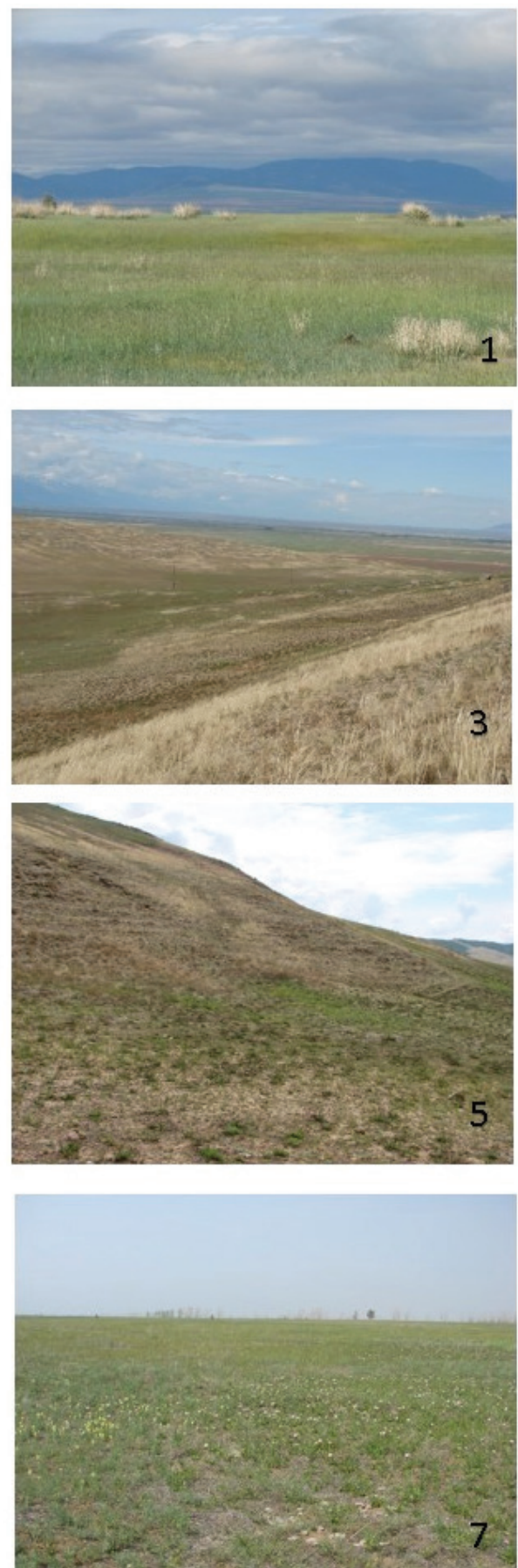
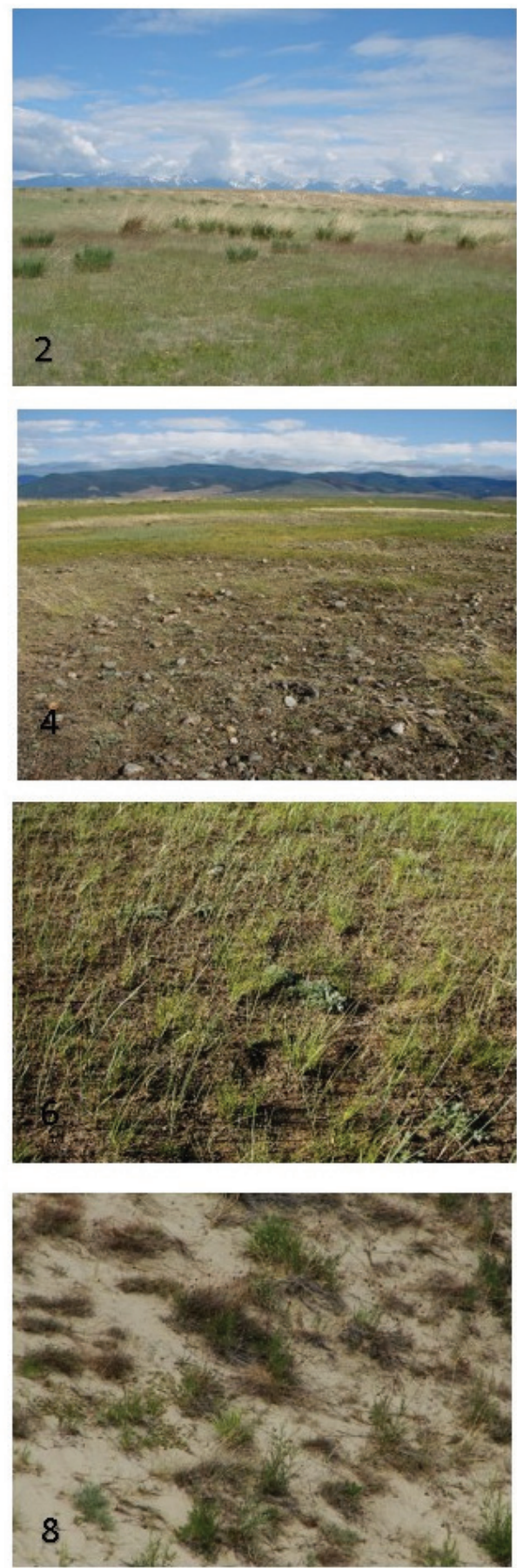

Puc. 2. Ландшафты Баргузинской котловины (1 - твердоватоосоковая степь, окрестности с. Могойто, 2 - окрестности с. Арзгун, твердоватоосоково-чиевая степь, терраса р. Гарга; 3 - ковыльная степь, окрестности с. Элэсун; 4 - твердоватоосоковая степь, окрестности с. Элэсун, IV в; 5 - хамеродесово-полынная степь, г. Кардига, окрестности с. Суво; 6 бесстебельнолапчатково-пульсатиллово-холоднополынная степь, окрестности с. Ина; 7 леймусово-вьюнковая степь на залежах, Верхний Куйтун, междуречье рек Аргада и Гарга, 8 - там же, песчаные гряды) 

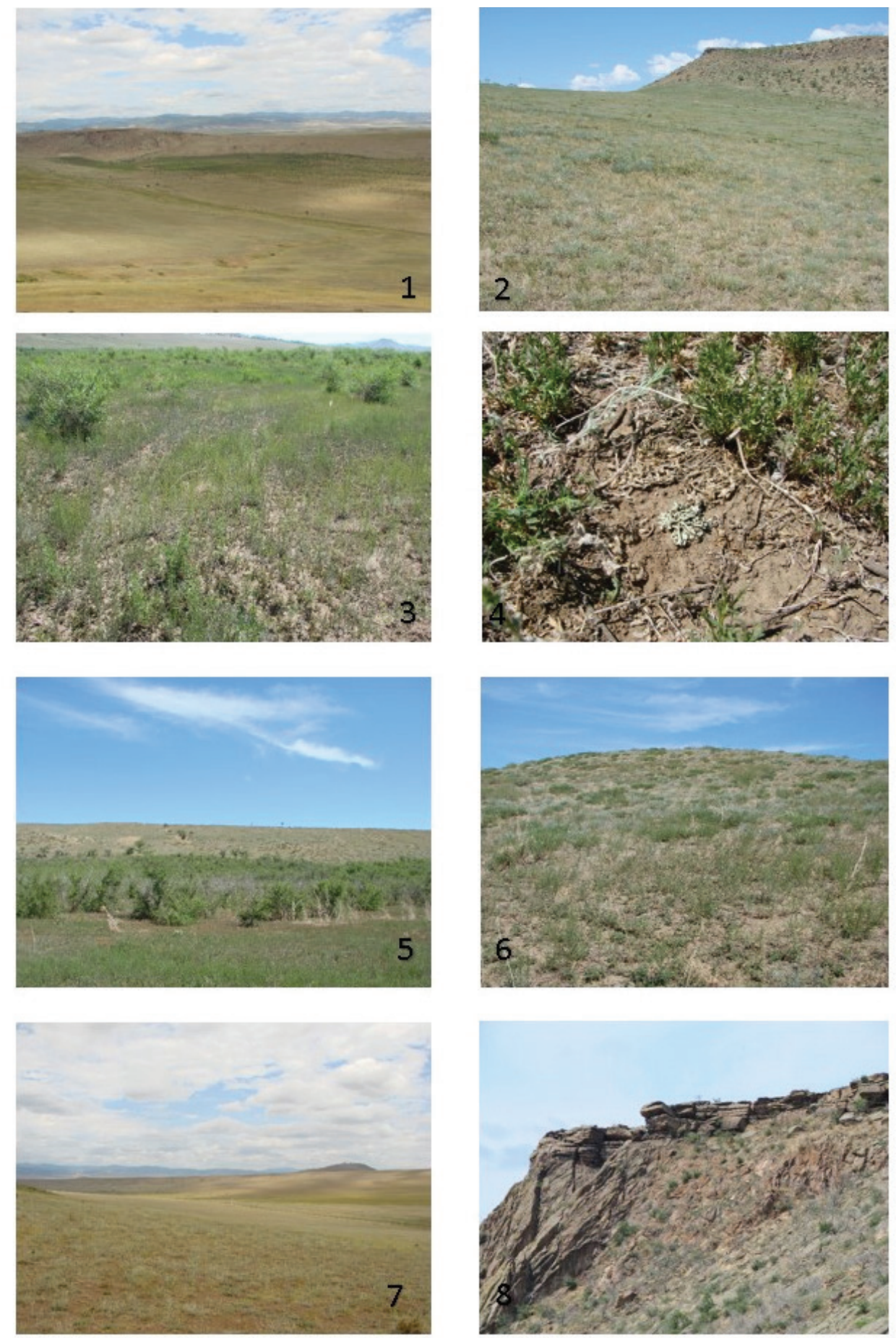

Рис. 3. Ландшафты Тапхарской котловины (1 - вид на Тапхарскую котловину; 2 холоднополынно-бесстебельнолапчатковая степь, склон юго-восточной экспозиции; 3 - дно котловины, бурьянистая залежь (солончак), сзади ильмовник; 4 - там же, таллом Xanthoparmelia camtschadalis; 5 - ильмовник разнотравный; 6 - полынно-карагановая степь, склон западной экспозиции; 7 - ковыльно-полынная степь, высокая равнина на останцовых горах; 8 - там же, склон западной экспозиции). 
VI. Курумканский район, окрестности с. Арзгун. VI a - терраса р. Гарга около

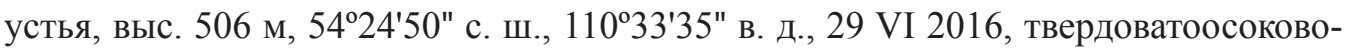
чиевая степь (Carex duriuscula C. A. Meyer. Achnaterum splendens (Trin.) Nevski, Leymus chinensis (Trin.) Tzvelev, Festuca lenensis Drobow, Plantago salsa Knorrig, Saussurea amara (L.) DC., Agropyron cristatum (L.) Beauv.); VI 6 (рис. 2.7, рис. 2.8) - Верхний Куйтун, песчаные гряды в междуречье рек Аргада и Гарга, выс. 603 м, 5420'39.6" с. ш., 110³6'44.9" в. Д., 25 VI 2016, леймусово-вьюнковая степь на старых залежах (Convolvulus arvensis L., Leymus chinensis (Trin.) Tzvelev), Chenopodium album L., Chamaerhodos erecta (L.) Bunge, Astragalus propinquus Schischk.); VI в - там же, подножие горы, выс. 683 м, 54¹9'07.4" с. ш., 110³8'08.6"в. д., 25 VI 2016, ковыльно-твердоватоосоковая степь (Stipa krylovii Roshev., Carex duriuscula C. A. Meyer, Pulsatilla turczaninovii Krylov et Serg., Aster alpinus L., Potentilla acaulis L., Artemisia frigida Willd.).

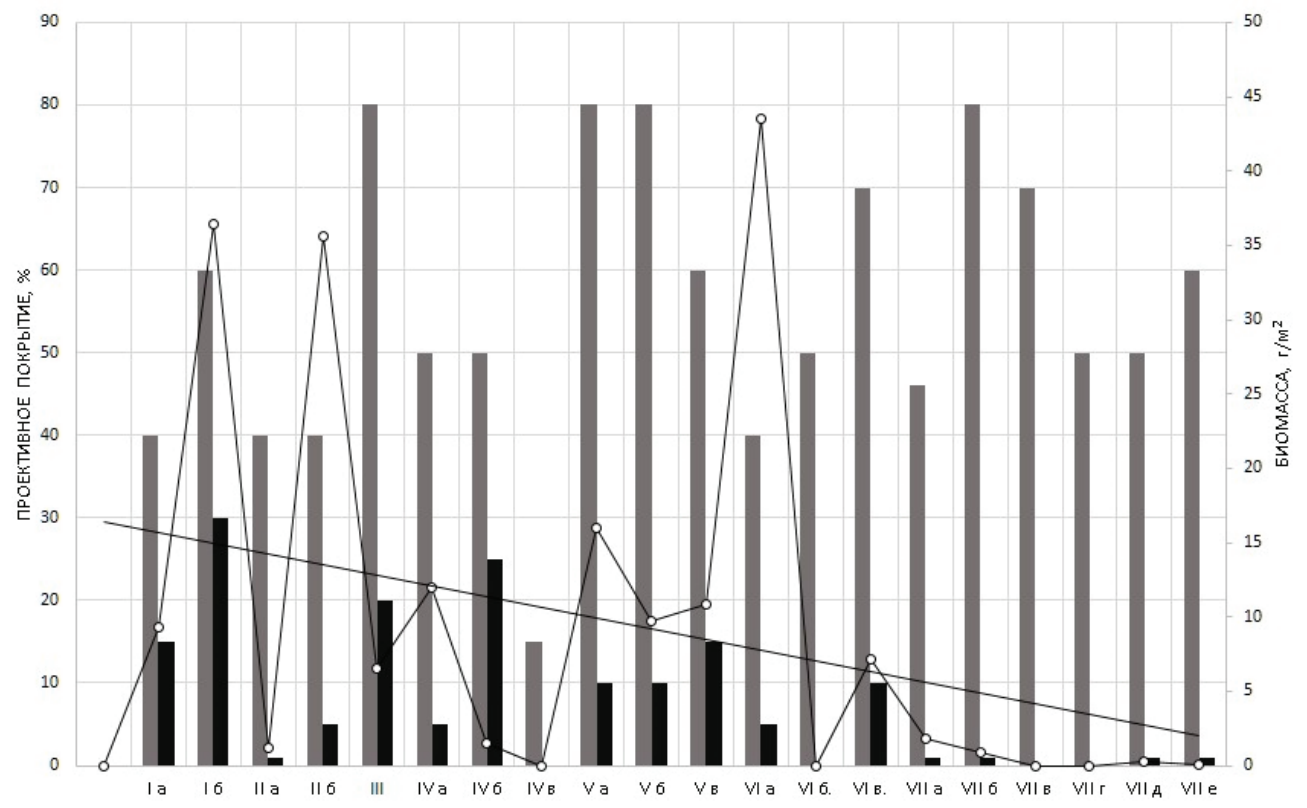

Puc. 4. Проективное покрытие сосудистых и Xanthoparmelia camtschadalis и биомасса Xanthoparmelia camtschadalis

Столбиками обозначены проективное покрытие сосудистых и Xanthoparmelia camtschadalis, точками - биомасса Xanthoparmelia camtschadalis с линией тренда

\section{Селенгинское среднегорье}

VII. Иволгинский район, хр. Ганзуринский, окрестности с. Тапхар. VII a пологий склон, $10^{\circ}, 51^{\circ} 44^{\prime} 27^{\prime \prime}$ с. ш., 107²0'43.3" в. д., выс. 543 м, 20 VI 2017, твердоватоосоково-холоднополынная степь (Carex duriuscula C.A. Meyer, Phleum phleoides (L.) Karsten, Artemisia frigida Willd., Potentilla bifurca L., Alyssum lenense Adams., Allium sp., Goniolimon speciosum (L.) Boiss., Artemisia commutata Besser, Agropyron cristatum (L.) Beauv.); VII 6 (рис. 3.1) — терраса, склон юго-восточной 


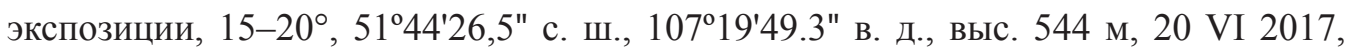
холоднополынно-бесстебельнолапчатковое сообщество (Artemisia frigida Willd., Potentilla acaulus L., Potentilla bifurca L., Alyssum lenense Adams, Allium sp., Agropyron cristatum (L.) Beauv., Stipa krylovii Roshev., Carex duriuscula C. A. Meyer, Phleum phleoides (L.) Karsten); VII в (рис. 3.3, рис. 3.4) - дно котловины, бурьянистая

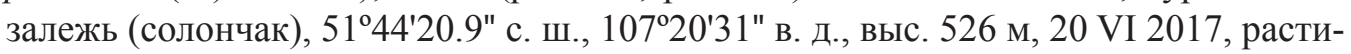
тельность рудеральная (Neopallasia pectinata Poljak., Artemisia commutata Besser, Panzerina lanata (L.) Sojak., Saussurea amara (L.) DC., Lappula sp.), голая почва с соляными выпотами, с продольной бороздчатостью (следы распашки); VII г

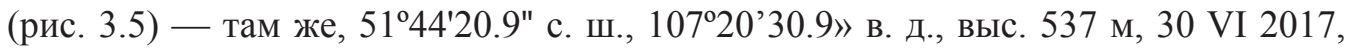
ильмовник разнотравный перед подгорным шлейфом (Ulmus pumila L., Agropyron cristatum (L.) Beauv., Leymus chinensis (Trin.) Tzvelev, Neopallasia pectinata (Pall.) Poljakov, Artemisia commutata Besser, Cynoglossum officinale L., Saussurea amara (L.) DC.); VII д (рис. 3.6, рис. 3.8) - склон западной экспозиции, 5\%, выс. 543 м, 51ํ4'27》 с. ш., 107²0'43.3" в. д., 11 VII 2017, полынно-карагановая степь (Caragana buriatica Peschkova, Spiraea aquilegifolia Pall., Artemisia frigida Willd., A. vulgaris L., Potentilla bifurca L., Dracocephalum nutans L., Dontostemon integrifolius (L.) C. A. Mey., Agropyron cristatum (L.) Beauv., Panzerina lanata (L.) Sojak, Allium sp., Serratula coronata L., Chamaerhodos erecta (L.) Bunge); VIIe (рис. 3.7) - высокая равнина на останцовых горах, выс. 572 м, 5104'33.2" с. ш., $107^{\circ} 20^{\prime} 48.9^{\prime \prime}$ в. д., 11 VII 2017, ковыльно-полынная степь (Stipa krylovii Roshev., Artemisia frigida Willd., Chamaerhodos erecta (L.) Bunge, Stellaria dichotoma L., Serratula coronata L., Vincetoxicum sibiricum (L.) Decne., Panzerina lanata (L.) Sojak.). Почва выбита скотом.

\section{Результаты}

Расчеты по шкалам пастбищной дигрессии, увлажнения и богатства-засоленности почв [Цаценкин и др., 1974] с помощью программы IBIS [Зверев, 2007] показали, что Хса в Баргузинской долине произрастает на богатых почвах $(13,4-$ 14,8 баллов по шкале богатства и засоленности почв). По характеру увлажнения фитоценозы с участием Хса занимают 10 ступеней (от 44 до 54 баллов), что соответствует сообществам с лугово-степным и сухолуговым режимами увлажнения. Согласно шкале пастбищной дигрессии, в настоящее время выпас в изученных местообитаниях слабый $(4,2-5,15$ балла).

В Тапхарской котловине экологические параметры сообществ с Xca по шкалам пастбищной дигрессии, увлажнения и богатства-засоленности почв колеблются в более узком диапазоне: пастбищная дигрессия от 4,74 до 5,79 балла, богатство-засоленность от 13,2 до 14,2 балла, по характеру увлажнения фитоценозы с участием Хса занимают 5 ступеней (ступени 45,3-50,2).

Таким образом, по составу сосудистых растений Хса относится к группе ксеромезофитов, произрастающих в условиях преимущественно степной зоны. Поскольку вид не прикреплен к субстрату, засоленность или трофность почв местообитаний влияет на него опосредованно, через формирующиеся фитоценозы. В местах его произрастания влияние выпаса по показателям пастбищной дигрессии слабое либо умеренное (табл. 1). 


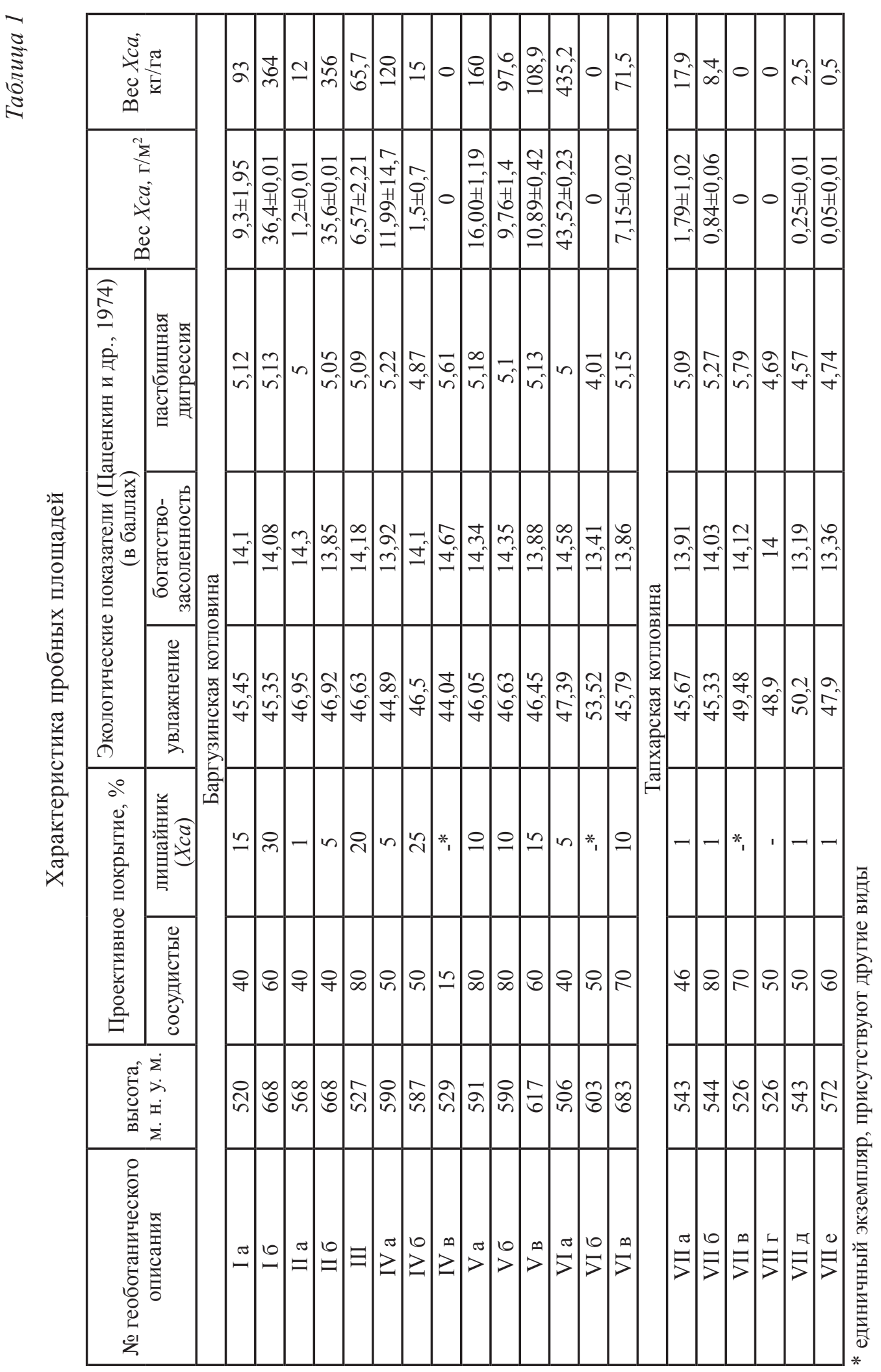


Проективное покрытие сосудистых растений в 2010-2016 гг. составляло в среднем $56 \%$ (80\% максимально) на малонарушенных вариантах сообществ и $50-70 \%$ на залежах (рис. 4). В Баргузинской котловине - 54\%, в Тапхарской котловине $-60 \%$. Разброс в значениях проективного покрытия лишайника (участки с доминированием $X c a$ ) колеблется от 1 до $30 \%$ (максимально), в среднем - $8 \%$. В то же время для Монголии указывается проективное покрытие: 9,7\% для Хэнтея [Hauck et al., 2007], 0,4-1\% для Хангая [Бязров, 2015]. Корреляционный анализ показал, что прослеживалась слабая корреляция как между проективным покрытием лишайника и его биомассой $-0,37$ (для Баргузинской котловины $-0,17$, для Тапхарской - 0,53), так и между проективным покрытием сосудистых растений и лишайника $-0,25$ (для Баргузинской котловины $-0,43$, для Тапхарской -0 ). Отрицательная корреляция прослеживалась между проективным покрытием сосудистых и биомассой лишайника $-0,08$.

Баргузинская котловина. Биомасса $Х c a$ от Икатского до Баргузинского хребта возрастала при движении с юга на север. Зависимости между значением биомассы и типом растительности, высотой над уровнем моря выделить не удалось. По пологим шлейфам горных склонов и межгорным понижений имеют широкое распространение ковыльные и разнотравные степи. По значениям веса биомасса варьировала от 15 до 120 кг/га, проективное покрытие сосудистых было максимальным, хотя проективное покрытие лишайников на склонах мало - от 1 до 5\%. На склонах Баргузинского хр. в окрестностях с. Кучигер биомасса Xca составляла 108,9 кг/га (V в, табл. 1). В чиевниках (высокие террасы рек Гарга, Ина, Баргузин) биомасса достигала 365-435,2 кг/га. На западном макросклоне Икатского хр. наибольшие значения биомассы $X c a$ отмечались в окрестностях с. Элэсун (подгорный шлейф) и около сел Ина и Суво при проективном покрытии сосудистых 40-50\%.

Твердоватоосоковые степи относятся ко вторичным, дигрессионным сообществам [Дулепова, 1993], особенно на пастбищах, как и бесстебельнолапчатковои холоднополынно-твердоватоосоковые степи. В центральной части котловины значения биомассы в твердоватоосоковых бесстебельнолапчатково- и холоднополынно-осоковые степях (V стадия антропогенной трансформации [Рупышев и дp., 2016]) на террасе р. Баргузин в пастбищно-деградированных фитоценозах при проективном покрытии сосудистых растений достигают 80\% (окрестности сел Могойто, Элэсун и Алла) (табл. 1) значения биомассы Xca колебались от 65,7 до 364 кг/га. При 7-й степени пастбищной дигрессии (IV в) проективное покрытие сосудистых составляет $15 \%$ с тремя видами, растительный покров одноярусный, Хса отсутствует, почвенный покров выбит.

В окрестностях с. Аргзун большие площади заняты залежными сообществами (VI б) и подвержены сильной пастбищной нагрузке в зимнее время. В леймусововьюнковой степи лишайники отсутствуют, однако на боковых склонах гряд встречаются единичные талломы $X c a$, но при этом развивались другие виды лишайников, чаще Endocarpon mongolicum H. Magn. и E. pusillum Hedw. На вершинах аккумулятивных песчаных возвышенностей (куйтунов) и подветренных склонах Xca не встречается. Дело в том, что поверхности гряд подвержены сильной ветровой эрозии - не прикрепленные слоевища уносятся ветром либо их засыпает песком, и лишайник погибает. 
На Селенгинском среднегорье в окрестностях с. Тапхар из-за антропогенного воздействия вид сохранился только на склоновых участках неудобных для сельского хозяйства. Проективное покрытие сосудистых в Тапхарской котловине неравномерное: на засоленных участках днища от 0-5 до 50\% (от центра солончака к окраине), а на плакорных участках и подгорных шлейфах - от 46 до 80\%. Проективное покрытие $X c a$ до $1 \%$, мозаичное. Единичные особи лишайника появляются на периферии залежей на дне котловины, где сильно выражено засоление, и сконцентрированы в степных сообществах на склонах. Хса обилен на пологих подгорных шлейфах, особенно на восточном, занятом холоднополынно-бесстебельнолапчатковой и твердоватоосоково-холоднополынной степями (рис. 3.1) (VII a, б) - 17,9 и 8,4 кг/га. На крутом западном склоне лишайник задерживается в дернинах трав и вокруг кустарников (Caragana buryatica, Spirea aquilegifolia). (VII д) - 2,5 кг/га. В ковыльной степи на высокой равнине (описания VII е) биомасса Хсa $-0,4$ кг/га.

Данные по биомассе $X c a$ в Бурятии согласуются с зарубежными данными. Л. Г. Бязров [Бязров, 1986] приводит значения биомассы Хса для Хангая (Монголия) от 22 до 1010 кг/га. В степях долины р. Шилин (Xilin-gol) (Внутренняя Монголия, КНР) масса лишайника $X c a$ составляет 15,6 кг/га на сильно стравленных участках в лапчатково-холоднополынных степях (Potentilla acaulis, Artemisia frigida, Cleistogenes squarrosa) и 9,6 кг/га на зимних пастбищах в леймусово-ковыльных степях (Stipa grandis P. Smirn., Leymus chinensis) [Holst et al., 2009].

\section{Обсуждение}

При анализе отношения биомассы сосудистых растений, взятых по литературным данным для Баргузинской котловины [Рупышев и др., 2016] и Селенгинского среднегорья [Убугунова и др., 2007], к биомассе лишайника коэффициент корреляции составил 0,6 в Баргузинской котловине, 0,5 - в Селенгинском среднегорье.

Соотношение биомассы сосудистых растений и Xca в Баргузинской котловине составляет в ковыльных степях (II стадия дигрессии) - 13:1, бесстебельнолапчатково-холоднополынных (III стадия дигрессии) - 16:1, твердоватоосоковых (IV стадия дигрессии) - 2:1 (табл. 2). Происходит постепенное увеличение запаса биомассы $\mathrm{Xca}$ - с 12 кг/га в субвискозополынно-чиевых сообществах до 93 кг/га в твердоватоосоковой степи. Стадии антропогенной трансформации даны по литературным данным [Рупышев и др., 2016]. В Баргузинской котловине при движении с севера на юг наблюдалось усиление пастбищной нагрузки, которая приводит к увеличению участия лишайников в сообществе. В Тапхарской котловине биомасса $X c a$ увеличивалась в холоднополынно-бесстебельнолапчатковой и твердоватоосоковой степях. В Тапхарской котловине биомасса сосудистых растений доминирует над биомассой $X c a$ в больших пропорциях (табл. 2), корреляции между проективным покрытием сосудистых и биомассой $X c a$ не обнаружено. Таким образом, в Бурятии биомасса $X c a$ в пастбищно-деградированных степных сообществах увеличивалась.

По наблюдениям, в Бурятии $X c a$ произрастает в естественных, как в малонарушенных, так и преобразованных выпасом, фитоценозах. По величине биомассы Xca выстраиваются следующие экологические ряды: твердоватоосоковые > ковыльно-разнотравные > чиевые > бесстебельнолапчатково-холоднополынные > залежи. 


\section{Таблииа 2}

Соотношение биомассы сосудистых растений и Xanthoparmelia camtschadalis

\begin{tabular}{|l|c|c|c|}
\hline Тип растительного сообщества & $\begin{array}{c}\text { Баргузинская } \\
\text { котловина }\end{array}$ & $\begin{array}{c}\text { Селенгинское } \\
\text { среднегорье }\end{array}$ & $\begin{array}{c}\text { Степень антропогенной } \\
\text { трансформации }\end{array}$ \\
\hline Твердоватоосоковые степи & $\frac{210.17}{36.26}$ & $\underline{310}$ & IV \\
\hline Ковыльные степи & $\underline{247.39}$ & $\underline{282}$ & II \\
\hline $\begin{array}{l}\text { Бесстебельнолапчатково- } \\
\text { холоднополынные степи }\end{array}$ & $\underline{\frac{88.92}{16.17}}$ & $\underline{40}$ & III \\
\hline Залежи & $\underline{231.32}$ & $\underline{30}$ & Бурьянистый перелог \\
\hline
\end{tabular}

* Примечание. Над чертой - биомасса сосудистых растений (по литературным данным), под чертой — лишайников (по собственным данным)

Сукцессионный ряд выглядит следующим образом. На залежах, в стадии бурьянистого перелога и в начале длиннокорневищной стадии, появляются отдельные слоевища $X c a$, но чаще встречаются накипные лишайники рода Endocarpon, а также Heppia lutosa (Ach.) Nyl., Rostania ceranisca (Nyl.) Otálora, P. M. Jørg. et Wedin. Залежи в аридных условиях восстанавливаются десятками лет [Гунин и др., 2019], и лишайниковый покров на них не исключение. Затем данные виды в развитых степных сообществах (разнотравно-ковыльных, мелкодерновинных степях) заменяются кустистыми видами рода Cladonia, такими как C. cariosa (Ach.) Spreng., C. cenotea (Ach.) Schaer., C. chlorophaea (Flörke ex Sommerf.) Spreng., C. pyxidata (L.) Fr., C. subulata (L.) Weber ex F. H. Wigg., и листоватыми лишайниками Хса и Phaeophyscia constipata (Norrl. et Nyl.) Moberg [Kharpukhaeva, 2013]. При этом возрастает обилие и проективное покрытие $X c a$. При выпасе домашнего скота изменяется видовой состав травостоев, а также разбивается мохово-лишайниковый покров. Поэтому в твердоватоосоковых и бесстебельнолапчатково-полынных, чиевых степях лишайниковый ярус представлен неприкрепленным листоватым видом - Xca, но при сильной пастбищной дегрессии $X c a$ исчезает. Так, ученые из Китая выявили, что при умеренной пастбищной нагрузке проективное покрытие и биомасса $X c a$ увеличиваются, а при экстремально большой пастбищной нагрузке, наоборот, сокращаются [Liu et al., 2004]. Экспериментальное подтверждение [Liu et al., 2009, по рис. 1Е) показало, что проективное покрытие Хса увеличивается с 5 до 15\% при увеличении пастбищной нагрузки, или на 200\%. Следует отметить, что сухие талломы лишайников чрезвычайно легко уничтожаются при палах, которые часто практикуются скотоводами. Таким образом, сообщества с одновидовым (из $\mathrm{Xca}$ ) лишайниковым ярусом не являются завершающим этапом развития степных сообществ, как считает Л. Г. Бязров (2015). Вслед за китайскими и немецкими учеными [Li et al., 2001; Liu et al., 2004; Liu et al., 2009; Holst et al., 2009] считаем, что проективное покрытие и биомасса $X c a$ зависят от уровня пастбищной нагрузки. $Х c a$ находится в оптимальных условиях при проективном покрытии сосудистых от 40 до 80\%. Причем высокий уровень проективного покрытия сосудистых 
растений вовсе не препятствует росту $X c a-$ в точке III (Могойто) максимальная биомасса $X c a$ при $80 \%$ проективного покрытия осоки твердоватой, или в точке IV б. Здесь главную роль играют особенности габитуса степных растений. Тонкие, практически нитевидные листья осоки, ковыля пропускают много света, к тому же травостой летом выгорает на солнце. Поэтому, несмотря на большое проективное покрытие сосудистых растений, Xca прекрасно развивается. Под воздействием пастбищной нагрузки снижается влияние травяного яруса на пространственное распределение $X c a$. Полное разрушение лишайникового покрова происходит при распашке земель и палах, а восстановление занимает годы - от 20 лет и свыше. $\mathrm{B}$ точках с максимальной биомассой $X c a$ выпас умеренный, а в окрестностях населенных пунктов и животноводческих стоянок показатели проективного покрытия сосудистых и $X c a$, а также биомасса последнего падают. Таким образом, наблюдается положительное влияние слабого либо умеренного выпаса на проективное покрытие и биомассу $X c a$, которые могут служить индикатором состояния травянистых экосистем.

\section{Литература}

1. Андреев В. Н. Прирост кустистых лишайников и приемы его регулирования // Труды БИН АН СССР. Сер. ІІІ, геоботаническая. 1954. № 9. С. 11-74

2. Балданов Б. Ц., Убугунова В. И., Рупышев Ю. А., Убугунов В. Л., Насатуева Ц. Н. Почвенно-растительное разнообразие степных экосистем Западного Забайкалья (на примере Тапхарских котловин) // Степи Северной Евразии: материалы конф. Оренбург, 2012. C. 93-97.

3. Бойков Т. Г., Харитонов Ю. Д., Рупышев Ю. А. Степи Забайкалья: продуктивность, кормовая ценность, рациональное использование и охрана. Улан-Удэ, 2002. 226 с.

4. Болданов Т. А., Мухин Г. Д. Экологическая адаптация сельскохозяйственного землепользования в условиях изменения климата в Республике Бурятия // Аридные экосистемы. 2019. T. 25, № 1(78). C. 10-19. DOI: 10.24411/1993-3916-2019-00040

5. Бязров Л. Г. Запас массы эпигейных макролишайников в некоторых горностепных сообществах Хангая (МНР) // Экология. 1976. № 2. С. 81-84.

6. Бязров Л. Г. О номенклатуре пармелии кочующей и запасах этого лишайника в Хангае // Природные условия и биологические ресурсы МНР. М.: Наука, 1986. С. 67-68.

7. Бязров Л. Г. Лишайники в сухих степях Восточного Хангая // Бюллетень МОИП. Отделение биологическое. 1988. Вып. 93(6). С. 66-80.

8. Бязров Л. Г. Участие лишайников в формировании биологических почвенных корок в степях Хангая (Монголия) // Аридные экосистемы. 2015. Т. 21, № 3(64). С. 64-71.

9. Гунин П. Д., Убугунов В. Л., Рупышев Ю. А., Убугунова В. И., Бажа С. Н., Балсанова Л. Д., Балданов Б. Ц., Буянтуева Л. Б., Харпухаева Т. М., Холбоева С. А., Петухов И. А., Цыремпилов Э. Г. О роли биотических и абиотических факторов в процессах закоривания почв залежных земель Баргузинской котловины // Аридные экосистемы. 2018. Т. 24, № 3(76). C. 11-24. DOI: 10.24411/1993-3916-2018-10022

10. Дулепова Б. И. Степи горной лесостепи Даурии и их динамика. Чита, 1993. 395 с.

11. Джураева 3. Лихенофлора Копетдага и ее эколого-ценотические аспекты: дис. ... д-ра биол. наук. Ташкент, 1993. 58 с.

12. Джураева 3. О видовом и синузиальном составе лихенофлоры равнинной части Юго-Западного Туркменистана // Эколого-биологические особенности доминирующих сообществ Юго-Западной Туркмении. Ашхабад, 1979. С. 28. 
13. Джураева 3., Абдурахимова 3. Продуктивность эпигейных лишайников глинистых пустынь // Бриолихенологические исследования в СССР. Апатиты, 1986. С. 91-98.

14. Закутнова В. И. Внедрение инновационной продукции исследуемой лихенофлоры семейства Parmeliaceae Eschw. Астраханской области // Естественные науки. 2013. № 2(43). C. $103-112$.

15. Зарубин А. М., Фролова М. В. Биологическая продуктивность надземной части природных кормовых угодий южной части Бурятии // Эколого-биологическая и хозяйственная характеристика степных и луговых растительных сообществ Забайкалья. Улан-Удэ, 1972. C. $115-123$.

16. Зверев А. А. Информационные технологии в исследованиях растительного покрова. Томск: ТМЛ-Пресс, 2007. 304 с.

17. Караваев М. Н. О составе синузии напочвенных лишайников в реликтовых степных сообществах Якутии // Ботанический журнал. 1976. Т. 61, № 7. С. 956-961.

18. Лысенко С. В. Изучение низших растений в полупустынях Западного Прикаспия в связи с почвенно-геоботаническими исследованиями // Ботанический журнал. 1963. Т. 48, № 11. С. $1610-1622$.

19. Магомедова М. А., Корытин Н. С., Ендукин А. Ю. Запас и структура фитомассы лишайников на оленьих пастбищах в высокогорьях Урала // Горные экосистемы Урала и проблемы рационального природопользования. Свердловск, 1986. С. 41.

20. Мангатаев Ц. Д., Намсараева М. А., Забанова Л. В. Пространственная неоднородность каштановых почв склоновых ландшафтов Забайкалья по агрохимическим показателям и биопродуктивности // Агро XXI. 2010. № 4-6. С. 26-27.

21. Меркушева М. Г., Лаврентьева И. Н. Биопродуктивность пойменных болотистых сообществ в сухостепной зоне Западного Забайкалья // Вестник Бурятского государственного университета. Сер. Биология, география. 2018. № 1. С. 5-16.

22. Меркушева М. Г., Убугунов Л. Л., Корсунов В. М. Биопродуктивность почв сенокосов и пастбищ сухостепной зоны Забайкалья. Улан-Удэ: Изд-во БНЦ СО РАН, 2006. 515 с.

23. Морозова Л. М., Эктова С. Н. Запас надземной фитомассы в горных лишайниковых и моховых тундрах полярного Урала в условиях интенсивного выпаса северных оленей // Горные экосистемы и их компоненты: тр. междунар. конф. Нальчик, 2007. С. 162-168.

24. Осипов К. И., Осипова Э. И. Сезонная динамика биологической продуктивности надземной массы типчаковых степей Западного Забайкалья // Эколого-биологическая и хозяйственная характеристика степных и луговых растительных сообществ Забайкалья. Улан-Удэ, 1972. С. 135-157.

25. Понятовская В. М. Учет обилия и особенности размещения видов в естественных растительных сообществах // Полевая геоботаника. М.; Л., 1964. Т. 3. С. 209-237.

26. Рещиков М. А. Степи Западного Забайкалья. М., 1961. 174 с.

27. Родин Л. Е., Ремезов Н. П., Базилевич Н. И. Методические указания к изучению динамики и биологического круговорота в фитоценозах Л.: Наука, Ленингр. отд., 1967. 145 с.

28. Рудьман Г. П. Заметки о растительности степей среднего течения р. Селенга // Эколого-биологическая и хозяйственная характеристика степных и луговых растительных сообществ Забайкалья. Улан-Удэ, 1972. С. 221-228.

29. Рупышев Ю. А., Убугунова В. И., Суткин А. В., Балданов Б. Ц. Внутрисезонные изменения состава, структуры и продуктивности дерновинно-злаково-полукустарничковых степей Западного Забайкалья (бассейн реки Иволга) // Вестник Бурятской государственной сельскохозяйственной академии им. В. Р. Филиппова. 2013. № 1(30). С. 81-88.

30. Рупышев Ю. А., Суткин А. В., Бойков Т. Г. Продуктивность степей Северного Прибайкалья в условиях различной трансформации // Разнообразие почв и биоты Северной и Центральной Азии: материалы III Всерос. конф. Улан-Удэ, 2016. С. 242-246. 
31. Рыкова Ю. В. Распространение и запасы лишайников на северо-востоке Якутии // Растительность и почвы субарктических тундр. Новосибирск, 1980. С. 124-139.

32. Самбыла Ч. Н. Запасы надземной фитомассы лишайниковых сообществ Тывы и их рациональное использование // Сибирский экологический журнал. 2007. № 14(2). С. 317-323.

33. Самбыла Ч. Н. Участие лишайников и мхов в запасе надземной фитомассы тундровых сообществ высокогорий Тувы // Известия Самарского научного центра Российской академии наук. 2014 № 16(5). С. 85-92.

34. Убугунова В. И., Меркушева М. Г., Убугунов Л. Л., Лаврентьева И. Н. Биологическая продуктивность и биохимический состав фитоценозов Иволгинской котловины (Западное Забайкалье) // Сибирский вестник сельскохозяйственной науки. 2007. № 9(177). С. 5-13.

35. Харпухаева Т. М. Разрастание лишайников и мхов на опустыненных землях в условиях Баргузинской долины // Экологические последствия биосферных процессов в экотонной зоне Южной Сибири и Центральной Азии: материалы междунар. конф. Улан-Батор, 2010. T. 1. С. 296-298.

36. Цаценкин И. А., Дмитриева С. И., Беляева Н. В., Савченко И. В. Методические указания по экологической оценке кормовых угодий лесостепной и степной зон Сибири по растительному покрову. М., 1974. 247 с.

37. Щелкунова Р. П. Прирост кормовых лишайников и их распространение на Енисейском севере // Ботанический журнал. 1979. Т. 64, № 8. С. 1111-1121.

38. Hauck M., Dulamsuren C., Mülenberg M. Lichen diversity on steppe slopes in the northern Mongolian mountain taiga and its dependence on microclimate // Flora. 2007. 202. Pp. 530-546. URL: http://dx.doi.org/10.1016/j.flora.2012.03.008 (accessed 03.08.2020)

39. Holst J., Butterbach-Bahl K., Liu Ch., Zheng X., Kaiser A., Schnitzler J. G., ZechmeisterBoltenstern S., Brüggemann N. Dinitrogen Fixation by Biological Soil Crusts in an Inner Mongolian Steppe // Biol. Fertil. Soils. 2009. № 45. Pp. 679-690. URL: https://doi.org/10.1007/ s00374-009-0378-7 (accessed 03.08.2020)

40. Kharpukhaeva T. M. 2013. Distribution and Biomass of Lichens and Mosses by Steppes in Barguzin Valley (Buryatia Republic) // Plant Biodiversity and Ecosystem Services in Continental Asia. Proc. of Int. conf. Ulaanbaatar, 2013. Pp. 43-44.

41. Li X., Xing X., Chen Z. Effect of Grazing Rate on Biomass and Element Composition of Xanthoparmelia Camtschadalis // Chin. J. Appl. Ecol. 2001. № 12(3). Pp. 369-373 (in Chinese).

42. Liu Hij., Han X., Li L., Huang J., Liu H., Li X. Grazing Density Effects on Cover, Species Composition, and Nitrogen Fixation of Biological Soil Crust in an Inner Mongolia Steppe // Rangeland Ecology \& Management Archive. 2009. № 62(4). Pp. 321-327. https://doi. org/10.2111/08-179.1 (accessed 03.08.2020)

43. Liu Z., Wang S., Han J., Wang Y, Chen Z. Distribution of Lichens Biomass and Its Affecting Factors during Restoration Process of Inner Mongolia Steppe // Chin. J. Appl. Ecol. 2004. Vol. 15. Pp. 1294-1296 (in Chinese).

\section{BIOMASS OF XANTHOPARMELIA CAMTSCHADALIS IN STEPPE COMMUNITIES OF BURYATIA}

\section{T. M. Kharpukhaeva}

Tatyana M. Kharpukhaeva

Cand. Sci. (Biol.)

Institute of General and Experimental Biology SB RAS

6 Sakhyanovoy St., Ulan-Ude 670047, Russia

takhar@mail.ru 
Abstract. The article analyzes the productivity and projective cover of Xanthoparmelia camtschadalis (Ach.) Hale in arid ecosystems of the Republic of Buryatia. Previously, the productivity of lichens in open grass ecosystems of Russia has not been studied. Xanthoparmelia camtschadalis is a xeromesophytic lichen of the Parmeliaceae family widespread in in arid and semi-arid steppes in Holarctic. The study was carried out in 2010-2016 based on our observations from transect investigations in the Barguzin depression from the slopes of the Ikat range to the foothills of the Barguzinsky range, and in the Tapkhar depression (Selenga middle mountains). The productivities were varied from 0.5 to $435.2 \mathrm{~kg} / \mathrm{ha}$ and 96.44 in average. We have found moderate positive correlations between lichen biomass and lichen coverage, and weak correlations between lichen biomass and plant community coverage. The coverage of lichens (areas with the dominance of $X$. camtschadalis) varies greatly from 1 to $30 \%$ with an average of $8 \%$. The changes of biomass and coverage of Xanthoparmelia camtschadalis had a good response to grazing rate, and it is an indicator of pasture impact on grassland ecosystems.

Keywords: Xanthoparmelia camtschadalis (Ach.) Hale; productivities; steppes; biomass; lichen; projective cover.

Статья поступила в редакцию 05.12.20; одобрена после редактирования 16.12.20; принята к публикации 18.12.20. 